\title{
An Analysis of Milton’s Free Will Defense From the Two Falls in Paradise Lost
}

\author{
ZHU Feng-mei \\ Ningbo Dahongying University, Ningbo, Zhejiang, China
}

\begin{abstract}
Paradise Lost is a great epic written by John Milton. Deeply influenced by Christian Humanism, Milton fully shows his free will defense in Paradise Lost. Based on the text of Paradise Lost, this paper mainly analyzes the causes of Milton's free will defense, his pursuit for free will shown in the two falls in the work: Satan's fall and Adam and Eve's fall. This paper also discusses the practical meaning of free will defense in Paradise Lost: it reveals his grief and anger of the failure of England revolution and shows the idea that people don't have the freedom to interfere or destroy other people’s free will.
\end{abstract}

Keywords: Milton, Paradise Lost, fall, free will defense

\section{Introduction}

Paradise Lost, Milton's best masterpiece, is a grand epic poem. He describes the fall of Satan and the fall of man in a poetic lyric. Based on Bible, Milton portrays God, Satan, Adam and Eve in this great work. From the fall of Satan, from an angel to evil, and the downfall of Adam and Eve, being driven out of the Eden, we find a very important thought under the lines, that is, the author's free will defense.

The so-called "free will defense" is "a traditional model to explain how God's omnipotence and goodness might indeed both be asserted, even given the fact that this world contains evil, particularly moral evil" (Danielson, 1982, p. 92). It would be rather good if there are angels and humans, but these creatures can't be free and automatic at the same time. Milton uses this famous thought to create a gorgeous work, and shows his own idea of free will defense. Milton uses this work to express his side; he proclaims his goal in writing this epic poem in Book I “To justify the ways of God to men” (Milton, 1993, p. 26). We can penetrate into the lines and find the idea there: he advocates free will defense, and he calls for free will defense.

This paper mainly wants to focus on Milton's free will defense thought through the analysis on the two falls of Paradise Lost. Deeply influenced by Christian Humanism, Milton fully shows his free will defense in Paradise Lost. Based on the text of Paradise Lost, this paper puts forward the examples of words and lines which imply Milton's pursuit for free will. This paper also discusses free will defense's meaning in the real society.

\section{Background of Milton's Free Will Defense}

The building up of Milton's free will defense has a very tight relation with his family background, education he got and the ethos of the society that he lived in. At the same time, there has been a long battle of 
Milton's theology, Calvinism or Arminism, which has influenced his free will and necessity. Therefore, we will discuss these factors in the following part.

\section{Family Background and Education}

John Milton is a well-known poet, politician, ideologist, and publicist in the 17th century in England. He was born in 1608 in a Puritan family of a well-do lawyer and private banker. He had progressive ideas when he was young and hated the old thinking of feudalism. He graduated from Christ's College, Cambridge University. He detested the graft and corruption of the church, so he abandoned his position in it. He started to write articles, probably because he found his best power was in writing.

At the time when the Puritan-Anglican conflict came to a head, a shape took in Milton's mind; it contained a gigantic struggle for freedom from all forms of tyranny. After the Puritan parliament had come to power, he wrote an influential article, Areopagitica (freedom of press), and articles in other fields.

From the governance of Charles I, to the first kingless Commonwealth and then the Protectorate of Cromwell, Milton came to realize the full liberty of his ideal commonwealth was too far to reach, though the theme of his works was always liberty.

Before Restoration in 1660, Milton was blind and in dangerous situation. With the strong hope for free will and his disappointments with the society, he dictated Paradise Lost. From the quotation follow-up:

He left it in thy power, ordaind thy will

By nature free, not over-ruled by Fate (Milton, 1993, pp. 526-527)

We may probably find Milton's advocacy: everyone's will is free by nature.

\section{Christian Humanism}

Milton's free will defense also has something to do with his belief and the ethos of that particular society.

John Milton is sometimes called as the Great Puritan poet because much of the prose works that he wrote supported the Parliamentary Party which insulted many non-Puritans. These people labeled him a Puritan as well because he shared some of the same beliefs as the Puritans. John Milton was not in fact a Puritan and he rejected all religions.

Actually Milton was an ardent Christian; he believed that while the Christian religion was the most important matter in life, it should only involve God, God's word and the individual human being. His literary thought, revolution practice was deeply rooted in the love for God and his only belief for God.

Meanwhile, there was also a great portion of humanism in the reason of the formation of Milton's free will defense. Humanism comes from humanus or humanistas in Latin. Humanism emphasizes the nature of human, and opposes divine right; uses individualism liberation to oppose stoicism and uses reason to be against obscurant. Humanism claims freedom of human beings. Milton's free will defense is just based on this reason supreme idea.

Almost all of the humanists at that time were Christians, who protested the corruption of Catholic churches. Milton was one of them, and as a Christian and a humanist, the belief in Christianity and the thought of humanism co-existed harmoniously, which made him gain a special name, a Christian humanist. He absorbed the essence of Christianity and humanism, which was in fact the reflection of politics and cultural ethos in last century.

Milton's Christian humanism is displayed in the following points: (1) the image of human beings is gorgeous; (2) his attitude towards knowledge is also be line with Humanism ideas, that is to advocate reason 
and truth, and be against obscurant and mystery; (3) his love for God, and the revealing of free will defense through describing God, God's son, Satan and Adam. The Christian humanism shown in Paradise Lost has displayed the wisdom and extensive knowledge of this great poet. In Paradise Lost, what Milton claims is that God must give human beings free will in order to praise the good and punish the bad; meanwhile, human beings have to take the responsibility and face the outcome caused by their free choice.

\section{Calvinism or Arminianism?}

Many scholars argue about Milton's theology: which is more influential, Calvinism or Arminianism? Samuel Johnson noted two centuries ago: “Milton’s theological opinions can be said to have been first Calvinistical, and afterwards, perhaps when he began to hate the Presbyterians, to have tended toward Arminianism” (Danielson, 1982, p. 59). Danielson also thought that “... recognition of Milton's adoption of an Arminian solution to some of the problems concerning divine justice renders a great deal less problematical the utterances of God in Paradise Lost... but it is surely fair to assume that where a Calvinist and non-Calvinist reading of a given passage are possible...". "Kelly has already shown how the Arminianism of the prose can illuminate potentially confusing statements in the poetry". For example, God's promise in book III of Paradise Lost, that "Man shall not quite be lost, but saved who will/Yet not of will in him but grace in me/Freely vouchsafed (III, 173-175)” (Danielson, 1982, p. 82). Milton’s God reacts to Man’s foreseeable fall by his plan of grace, and it is by this action that we understand more clearly Milton's disagreement with Calvinism. Milton's idea of grace is not "irresistible”, but "conditional” upon Man's choice to accept or refuse it. By adopting the Arminian position on predestination, grace, and free will, Milton is able to avoid both Pelagianism on the one hand and the theodically dissonant aspects of Calvinism on the other. Therefore, in the author's opinion, Arminianism has played a more important role in the free will idea in Paradise Lost.

To be concluded in this part, Milton's free will defense is profound and radical. With various kinds of reasons, his free will defense came into being and developed and was displayed in his works, Paradise Lost in especial. He expressed his thought-provoking free will defense in the mouths of God, God's son, Satan, Adam and Eve deeply and completely.

\section{Display of Milton's Free Will Defense in Paradise Lost}

As mentioned above, Milton's free will defense was fully shown in all kinds of characters in Paradise Lost, through their words and argument we find Milton's view on free will. Eleanor Roosevelt once said, "Remember always that you not only have to be an individual, you have an obligation to be one". To be an individual means to act by choice and make decisions with free will enhanced by the power of knowledge. Only then are people true to themselves and to others. In Paradise Lost, Milton clearly conveys this concept of acting freely under God. For example, he expresses his idea of "Reason is Choice" in the tone of God:

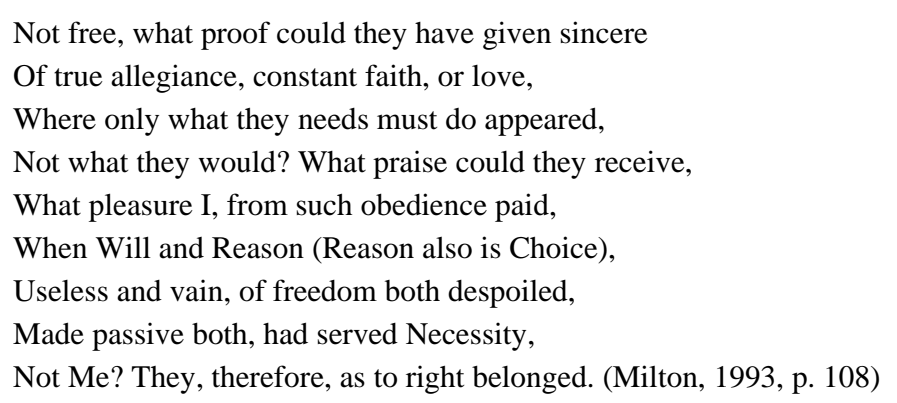


Milton shows us that everyone should be given the right to choose, and then hisher action can be meaningful. That's why Milton designed the fall of human in Paradise Lost. Human beings should have the choices to make their own decisions, and then take the responsibility by them, no matter the decision is right or wrong. Actually, the free will in Paradise Lost is not only shown in the fall of human, but also the fall of Satan, and many other Satan's followers, whose fate further illustrate the importance of free will. The display of free will mainly falls in Book III, V, VIII, and IX. The follow-up part will illustrate this from the two falls: Satan's and Adam's.

\section{Satan's Fall}

Satan is a complicated character in Paradise Lost, who is created by Milton as evil He was fallen before Adam and Eve fell. It is him who seduced Eve to eat the "forbidden fruit". Somebody holds the idea that Satan is the real hero in Paradise Lost. And actually, Milton did describe Satan as a hero unconsciously. But Satan couldn't receive the salvation from God, because his fall is an unfortunate fall, comparing to the fortunate one of Adam and Eve. From the fall of Satan, we may find Satan probably is the bravest character who pursuits his own incomparable free will, which can be illustrated by the following lines and quotations:

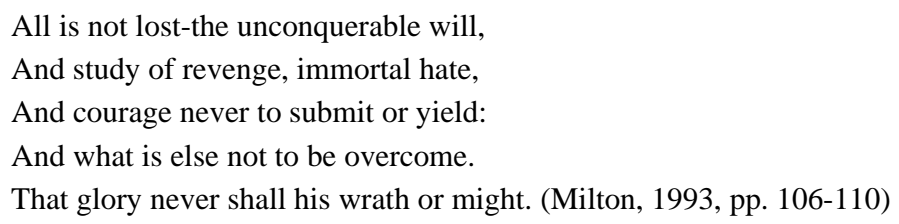

Satan is really a humanistic hero who realizes his infinite potential, and dares to doubt everything, to negate everything. He made his choice; chose to rebel the power of God, out of his own will, no matter it is right or wrong. In Satan's later words we can find the free will defense:

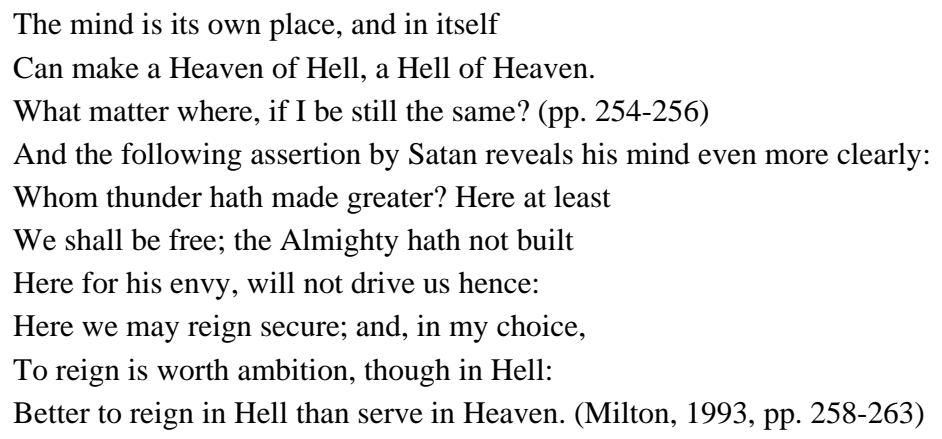

The fall of Satan and the fall of Adam are of the same reason: betray of God, but Satan's real fall is to seduce human beings to fall. In Milton's opinion, no one has absolute freedom; no one has the freedom to interfere other people's freedom. That is to say, there should be a limit or restraint in the free will, which is under the condition that you've put the God's words as the premise. Satan interferes other's free will; therefore, he can't be forgiven.

\section{Adam and Eve's Fall}

The key part of Paradise Lost lies in the fall of Adam and Eve. God's first human creation, Adam, was given all luscious gifts of paradise, including free will. The Tree Of Knowledge was Adam and Eve's only forbiddance. Once they ate fruits of the tree, their pureness would vanish. Eve was Adams partner, soul mate, 
and wife. Made from a rib of Adam, Eve was of him, part of him and belonged to him. She knew no other knowledge other than what was taught and told through Adam. On the day she was created, Fragile and susceptible, Eve awoke with beauty and from that day forth, back in her mind lay vainness.

The theme of Milton's Paradise Lost is to “justify the ways of God to man” (Milton, 1993, p. 26), to prove that it is fair for God to drive Adam and Eve out of Eden and "Brought death into the world and all our woe" (Milton, 1993, p. 3) because they had eaten the "fruits of the Forbidden tree”. Since Human beings' will is free by nature, they can make their decision, have the choice, but they also have to be responsible for what they have done and their own fate.

Unlike Satan, Adam and Eve understand that their disobedience to God does not know that their disobedience will be corrected through generations of toil on Earth. This path is obviously the correct one to take: the visions in Books XI and XII demonstrate that obedience to God, even after repeated falls, can lead to humankind's salvation.

Along with Adam and Eve's fall and confess, we may find a lot of human beings' free will defense. The follow-up part will show us a close look.

Firstly, after Eve stole the forbidden fruit and asked Adam to take one, Adam thought painfully for a while and made his first free choice in Eden. Facing the question of "to eat or not to eat", he chose to eat out of his love for Eve and his own free will. We may feel Adam's great sorrow while making the decision in the following lines:

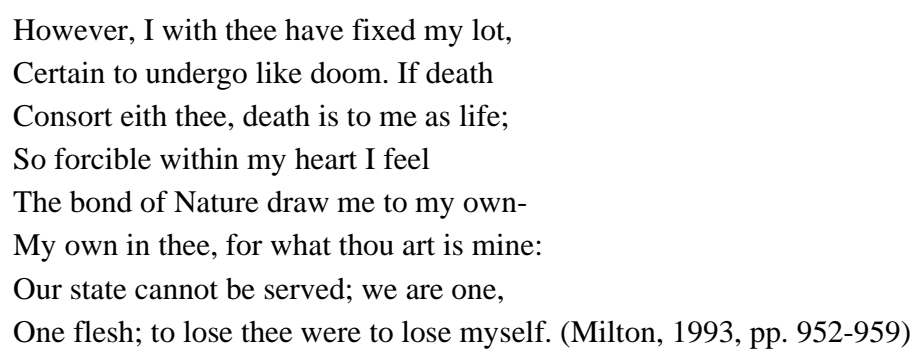

From the above lines, we can see Adam, as a human created by God, loves his companion Eve very much. After thinking and suffering from dilemma, he chooses to be loyal to his lover, to accompany her in the way of eating the "forbidden fruit". His "we are one, one flesh, to lose thee were to lose myself" strongly impresses us. That's the choice Adam made by himself, out of free will, out of his sincere love for Eve. The following quotation further explains Adam's free will and Milton's free will defense:

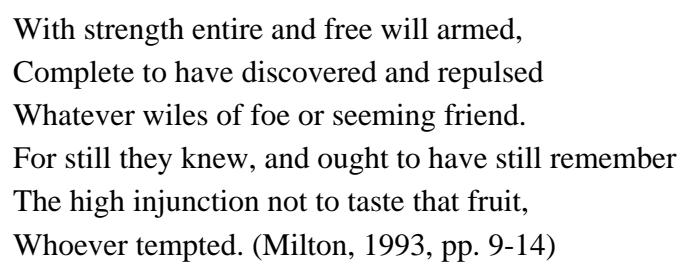

In this quotation, we are prodded to remember God's high injunction and its demonstrated consistency with free will. In this way, Milton transforms it into a literary resource for facilitating his poetic justification of God to men.

Next come Adam's complaints and deep woe: 
Did I request thee, Maker, from my clay

To mould me Man? Did I solicit thee

From darkness to promote me, or here place

Concurred not to my being, it were but right

Abd equal to reduce me to my dust,

Desirius to resign and render back

All I received, unable to perform

Thy terms too hard, by which I was to hold

The good I sought not. To the loss of that

Sufficient penalty, why hast thou added

The sense of endless woes? Inexplicable. (Milton, 1993, pp. 743-754)

Then Adam and Eve suffered after fall and were full of repentance, because their fall brought disaster to their descendants: death, hard work, floods, and so on. And they felt sorry about what they had done to God. Actually, the love for God is more sincere than before the fall, which will certainly make God more satisfactory:

Fruits of more pleasing savour, from thy seed

Snow with contrition in his heart, than those

Which, his own hand manuring, all the trees

Of Paradise could have produced, ere fallen

From innocence. Now therefore, bend thine ear (XI, 26-30)

Finally, after the spiritual struggling, Adam made his decision:

Henceforth I learn that to obey is best,

And love with fear the only God, to walk

As in his presence, ever to observe

His providence, and on him sole depend,

Merciful over all his works, with good. (Milton, 1993, pp. 561-565)

He said he learned that "to obey is the best", "love with fear the only God", therefore, he decided to choose God and Reason. In the expectation of God, out of free will again, human beings choose to obey God and have the free will under God.

All these choices and changes are out of Adam's free will, which implies Milton's assertion: everyone has the free will to choose and to be responsible for the outcome of their decisions.

In fact, the fall of Adam is necessary, and foreseen by God. This is an inevitable step for human beings to be a real person. Therefore, we may call the fall of Adam "a fortunate fall". Since then, they may find a happier Eden:

Of all the rest: then wilt thou not be loth

To leave this Paradise, but shalt possess

A Paradise within thee, happier far. (Milton, 1993, pp. 585-587)

From the fall of Adam, we can come to a conclusion of Milton's view on free will, that is, human beings are endued with the right to choose freely, but the first priority is God's. They have to respect God and trust God, then human beings can gain the free will.

\section{Practical Importance of Free Will Defense}

Milton lived in a complicated situation: dramatic social changes, conflicts between the new and the old 
ideas, fights between the new and the old forces, reformation and revolution. Paradise Lost was created right in that specific period of time. Some scholars treat Paradise Lost as a revolution epic, because it was written when England was in turmoil. The author of this paper holds that idea that the free will defense in Paradise Lost has two aspects of practical meanings: the first one is to Milton's reflection on England revolution. He is a fighter in the revolution. It reveals his grief and anger of the failure of England revolution, and his wish for the coming revolutions for free will and rights in England; the second one is to show the idea that people don't have the freedom to interfere or destroy other people's free will.

\section{Conclusion}

Milton's Paradise Lost is grand, great and gorgeous. As a devout Christian and a humanist in a certain society, the writer creates such a marvelous masterpiece, conveying his view on free will. The main part to show the author's opinion about free will is the double falls: one angelic and the other humanistic. Satan's fall arose from his strong desire of freedom, of getting rid of being ruled and controlled by God. It is a fall beyond repair, because he tried to seduce human beings to disobey God. In Milton's opinion, no one can interfere other's free will. While on the other hand, Adam and Eve's fall is on the contrary, they gained salvation and found a happier paradise in them. This fall conveys us the sign that human beings have the right to make their own decisions, free will in other words. They can act freely and follow their heart only if they put their love and belief for God firstly, and take the responsibility by themselves. In that way can they have the true free will. Meanwhile, no body can ignore or destroy other people's freedom is also an assertion by Milton. Free will defense shows Milton's wisdom and bravery in that society. The inspiration he gives us is: we are all individuals with our own respect ideas; we should act freely, and show our individualism and never take away other's free will for the sake of yours.

\section{References}

Danielson, D. R. (1982). Milton's good God-A study in literary theodicy. London, New York, New Rochelle, Melbourne, Sydney: Cambridge University Press.

Empson, W. (1981). Milton’s God. London, New York, New Rochelle, Melbourne, Sydney: Cambridge University Press.

Hunter, G. K. (1980). Paradise Lost. London, Boston, Sydney: George Allen \& Unwin.

Milton, J. (1993). Paradise Lost. In R. Flannagan (Ed.). New York: Macmillan.

Pattison, M. (2011). Milton. Charleston: Nabu Press.

Selden, R., Widdowson, P., \& Brooker, P. (2004). A reader's guided to contemporary literature theory. Beijing: Foreign Language Teaching and Researching Press.

Simmonds, J. D. (1973). Milton studies v. London: University of Pittsburgh Press. 